Research Article

\title{
Antimicrobial Potency of Ayurveda Principle based HSP Mixture for Gargling, Steam Inhalation, and Nebulisation in Prevention and Early Management of SARS-COV-2 Disease
}

\author{
CD Ravi Raj
}

Ayurveda Physician \& CEO, Dr Jains Health Care Services, Savlanga Road, Opp. Karnataka Bank, Shivamogga, Karnataka, India. DOI: https://doi.org/10.24321/2394.6547.202103

\section{I $\quad \mathbf{N} \quad \mathbf{F}$}

E-mail Id:

cdraviraj@gmail.com

Orcid Id:

https://orcid.org/0000-0001-6191-9932

How to cite this article:

Raj CDR. Antimicrobial Potency of Ayurveda Principle based HSP Mixture for Gargling, Steam Inhalation, and Nebulisation in Prevention and Early Management of SARS-COV-2 Disease. J Adv Res Ayur Yoga Unani Sidd Homeo. 2021; 8(1\&2): 10-13.

Date of Submission: 2021-05-28

Date of Acceptance: 2021-06-23

\section{$\begin{array}{llllllll}\mathbf{A} & \mathbf{B} & \mathbf{S} & \mathbf{T} & \mathbf{R} & \mathbf{A} & \mathbf{C} & \mathbf{T}\end{array}$}

\begin{abstract}
Introduction: The SARS-COV-2 disease has become the strongest among all the deadly respiratory diseases in taking the lives of lakhs of humans. The current study adopts the Ayurvedic principle of Samprapti Vighatana i.e. arresting the pathogenesis, through the usage of a novel selfformulated medicine powder named Haridradi Steam Powder (HSP) which is an anti-microbial decoction used for gargling, steam inhalation therapy, and nebulisation in the prevention of SARS-COV-2 disease by reducing the viral load in patients.
\end{abstract}

Methodology: Haridradi Steam Powder (HSP) containing decoction for gargling, steam, and nebulisation by adding $3 \%$ normal saline were prepared and given to the -participants as per self-made protocol i.e. gargling was advised for primary contacts, asymptomatic patients, and healthy persons as a preventive tool. High-pressure steam inhalation was advised for mild to moderate symptomatic patients and 3\% normal saline nebulisation was advised for moderate symptomatic patients.

Results: Out of the total of 30 cases, comprising 22 primary contacts, 3 HRCT atypical viral pneumonia with severity score from 8 to 16,3 RTPCR positive patients, and 2 RT-PCR positive patients with HRCT score, a marked improvement was seen in more than 20 subjects within a short span of time.

Conclusion: The treatment formulation HSP Mixture is found to be effective yet simple, safe, and cost-effective, and is used in different therapies in the prevention and management of early SARS-COV-2 disease.

Keywords: HSP (Haridradi Steam Mixture), SARS-COV-2 Disease, Samprapti Vighatana 


\section{Introduction}

Since centuries, Ayurveda has been providing effective curative measures for the management of such diseases and encompasses a wide range of therapeutics to get rid of such diseases. The current study adopts the Ayurvedic principle of Samprapti Vighatana i.e. arresting the pathogenesis, through the usage of a novel self-formulated medicine powder named Haridradi Steam Powder (HSP) which is an anti-microbial decoction used for gargling, steam inhalation therapy, and nebulisation in the prevention of SARS-COV-2 disease by reducing the viral load in diseased patients. The objective of this experiment was to analyse the efficacy of the combination of Haridradi antimicrobial gargling, steam inhalation therapy and herbal antimicrobial nebulisation including 3\% normal saline on mild to moderate SARSCOV-2 disease.

\section{Materials and Methods}

Haridradi Steam Powder (HSP) containing decoction for gargling, steam, and nebulisation by adding 3\% normal saline therapies were prepared and given to patients as per self-made protocol. Gargling was advised for primary contacts, asymptomatic patients and healthy persons as a preventive tool. High-pressure steam inhalation was advised for mild to moderate symptomatic patients and $3 \%$ normal saline nebulisation was advised for moderate symptomatic patients. Haridra (Curcuma longa Linn.) popularly known as turmeric is the main ingredient in HSP.

Preparation of Medicine - A. Medicated decoction preparation for gargle - $1 / 4$ TSF of Haridra (turmeric), and Saindhava lavana (black salt) were added to $250 \mathrm{ml}$ of water and boiled till a decoction is prepared. This lukewarm decoction preparation was advised for oral rinsing and gargling for 15 minutes. B. Medicated steam preparation In a pressure cooker, $3 / 4$ TSF of Haridradi powder (turmeric powder, black salt) was added to $2 \mathrm{~L}$ of water, the safety valve was replaced with the rubber gas pipe, and whistle and rubber gasket were put. This was kept over medium flame till steam was generated. As a safety precaution, water spilling from the rubber pipe was reduced by letting down the opening of the pipe towards the floor to drain the extra hot water present in the pipe. Steam was to be inhaled from the mouth for 8-10 minutes.

Haridra contains curcumin, a chemical substance that has anti-viral effects against different respiratory viruses. Inosine monophosphate dehydrogenase (IMPDH) is an enzyme used for targeting different viruses and cancer cells. The active principle process ${ }^{1}$ different bioconjugates of this curcumin are potentially best against different viruses like PIV-3, HSV, FLOCK HOUSE VIRUS, and Respiratory Synctial Virus. ${ }^{2}$

The active principle curcumin of Haridra has shown antiviral activity over influenza viruses like PR8, H1N1, and H6N1. ${ }^{3}$
SARS-CoV-2 inoculation and viral replication in humans host occur mainly through three major proteins and enzymes. These proteins are the papain-like protease (ACE2), spike protein (TMPRSS2), and the 3 chymotrypsin-like protease (3CLpro) (Figure 1).

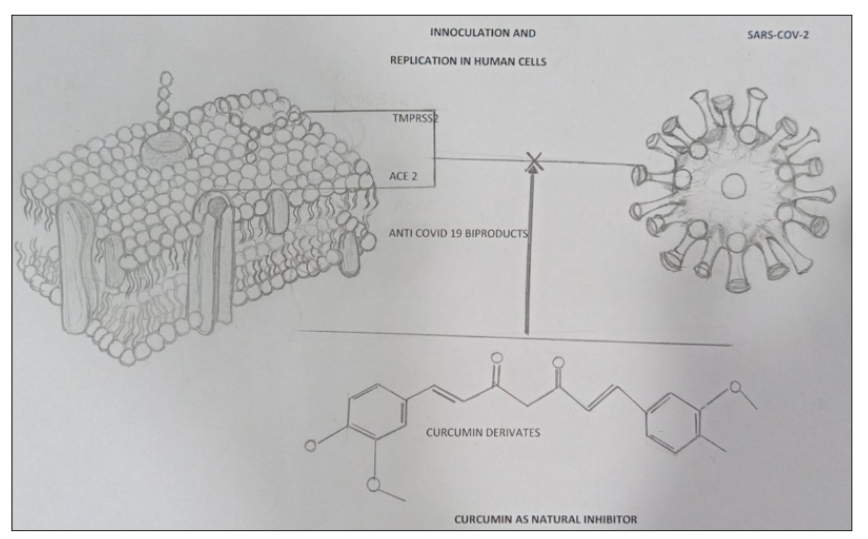

Figure I. Effect of Curcumin as Natural Inhibitor

The main protein of SARS-CoV-2, 3CLpro prevents the virus inoculation on the host.

By their molecular docking effect, the natural metabolites inhibit the 3CLpro of SARS-CoV-2, uplifting the prominent results of curcumin and other important flavonoids. ${ }^{4}$

The above natural chemicals are inhibitors of the 3 CLpro cov-2.

Medicated Gargle: Medicated Haridradi powder (containing fine turmeric powder and black salt) decoction can be used for gargling and mouth rinsing. Medicated oral gargling reduces viral load in salivary glands, oral cavity, and upper respiratory tract. This oral gargling is called as kavala (oral rinse) and gandusha (gargle). ${ }^{5}$

Bacterial and viral URTI are usually controlled by simple gargling. ${ }^{6} \mathrm{It}$ is a unique therapy to flush out the viruses. It damages the lipid envelope of the coronavirus from salivary glands and upper respiratory tract. ${ }^{7}$

Throat and salivary glands are the sites of viral replication and the main source of transmission of SARS-COV-2 too. SARS-CoV-2 has an envelope and outer membrane with a lipid layer. It is usually derived from the host cells. It is also highly sensitive to agents that disrupt lipid biomembranes. Thus throat and salivary glands are said to be the major sites of virus replication and transmission during early coronavirus disease 2019 , thereby advocating the application of oral antimicrobials. ${ }^{8}$

Steam Therapy: Medicated herbal antimicrobial containing steam inhalation helps in the reduction of viral load in the upper and lower respiratory tract. Steam inhalation is being used since hundreds of years for several respiratory conditions like common cold, wheezing, asthma, and bronchitis. $^{9}$ 
The reason behind the usage of steam was to reduce the replication of human rhinovirus which is a common microorganism that causes common cold in vitro at the temperature of 33 to $43^{\circ} \mathrm{C} .10$

In the case of an inflamed upper respiratory tract with cough, cold, and sore throat, steam inhalation smoothens the inflamed mucous of the upper respiratory surface, reduces the viscosity of the phlegm and mucus, and makes airflow easy. ${ }^{11}$

The helpful effects of the practice of bending over a bowl of boiling water on Corona infections in the Philippines got the attention of doctors. ${ }^{12}$

Steam generated from a pressure cooker and boiling water has a temperature of about $70{ }^{\circ} \mathrm{C}$ to $80^{\circ} \mathrm{C}$ and this is sufficient to destroy SARS-CoV-2. The influenza virus in humans and guinea pigs showed a similar pattern with many getting inactivated above the temperature of $30^{\circ} \mathrm{C} .{ }^{13}$ In another study, the SARS-CoV-2 at the temperature of 70 ${ }^{\circ} \mathrm{C}$ incubation made inactive from 14 days to 5 minute. ${ }^{14}$

Nebulisation: This is done with 3\% NS and herbal antimicrobial containing nebulising solution. Mist nebulisation therapy is used in hospitals and many developed countries because of its uniformity and safety of delivery. ${ }^{15}$

Early reduction of complications, high oxygen dependence, and ventilator dependence may be reduced by $3 \%$ by using normal saline mixed with filtered herbal anti-microbial liquid. There is less chance of secondary bacterial growth because of a decline in the inflammation within the airways. Mucociliary performance gets better which helps in the elimination of intracellular debris.

$3 \%$ NS nebulisation is an effective and safe therapy for viral infections and secondary acute bronchiolitis. ${ }^{16}$

\section{Results}

22 primary contacts, 3 HRCT atypical viral pneumonia with severity score from 8 to 16, 3 COVID-19 RT-PCR positive patients, 2 RT-PCR positive with HRCT score more than 20 had visited Amrutha Sanjeevini Clinic, Shimoga, Karnataka between 20.04.2021 and 18.05.2021. All these individuals were subjected to gargling + steam inhalation, medicated steam inhalation, gargling + steam inhalation + nebulisation therapy respectively as mentioned above. A marked improvement was seen in all these 30 cases within a short span of time. One among these patients, who had severe pneumonia, was being managed in a local hospital. His condition was gradually improving with less oxygen dependency.

\section{Discussion}

COVID-19 is a highly contagious illness that is transmitted from one person to another through contaminated respiratory and salivary droplets.
SARS-CoV-2, which causes COVID-19 disease, was found in Wuhan, Hubei Province, China in December 2019. ${ }^{17}$ The transmission of the virus occurs through the upper respiratory tract including the nose, nasopharynx, buccal cavity, salivary glands, pharynx, and larynx with more quantity of viral shedding. ${ }^{17}$

\section{Conclusion}

Gargling with herbal antimicrobial decoction, salt, and 3\% NS, steam inhalation and nebulisation are economical, effective, and simple therapies in the prevention and management of early SARS-COV-2 disease. This unique protocol contains 4000-year-old time tested Ayurvedic medicine and procedures blended with modern scientific technique, to destroy the virus in the salivary glands, and upper and lower respiratory tract. This helps in the reduction of viral load, decreases the alveolar complications, and clears the airway with inflammatory debris maintaining normal oxygen levels in the blood. Adopting this protocol in prevention, high-risk groups, asymptomatic cases, and mild to moderate cases shall dramatically reduce the complications, oxygen dependency, and deaths in SARSCOV-2 disease. Mandatory HSP gargle and HSP steam inhalation must be adopted for the prevention of SARSCOV-2 disease. Radiological atypical pneumonia patients must be started with HSP nebulisation at the earliest to prevent complications and to minimise hospitalisation.

Source of Funding: It is a self-funded project

\section{Conflict of Interest: None}

\section{References}

1. Dairaku I, Han Y, Yanaka N, Kato N. Inhibitory effect of curcumin on IMP dehydrogenase, the target for anticancer and antiviral chemotherapy agents. Biosci Biotechnol Biochem. 2010;74(1):185-7. [PubMed] [Google Scholar]

2. Singh RK, Rai D, Yadav D, Bhargava A, Balzarini J, Clercq ED. Synthesis, antibacterial and antiviral properties of curcumin bioconjugates bearing dipeptide, fatty acids and folic acid. Eur J Med Chem. 2010;45(3):1078-86. [PubMed] [Google Scholar]

3. Chen DY, Shien JH, Tiley L, Chiou SS, Wang SY, Chang TJ, Lee YJ, Chan KW, Hsu WL. Curcumin inhibits influenza virus infection and haemagglutination activity. Food Chem. 2010;119(4):1346-51. [Google Scholar]

4. Antonio AS, Wiedemann LSM, Veiga-Junior VF. Natural products' role against COVID-19. RSC Adv. 2020;10:23379. [Google Scholar]

5. Trikamji J. Sushrutha: Sushrutha Samhita with commentary of Dalhana. 40th Chapter, Verse 63-65. Chikitsa Sthana, Varanasi: Chowkhambha Surabharthi Prakashan, 2009. p. 553, 824.

6. Satomura K, Kitamura T, Kawamura T, Shimbo T, 
Watanabe M, Kamei M, Takano Y, Tamakoshi A, Great Cold Investigators-I. Prevention of upper respiratory tract infections by gargling: a randomized trial. Am J Prev Med. 2005 Nov;29(4):302-7. [PubMed] [Google Scholar]

7. O'Donnell VB, Thomas D, Stanton R, Maillard JY, Murphy RC, Jones SA, Humphreys I, Wakelam MJO, Fegan C, Wise MP, Bosch A, Sattar SA. Potential Role of Oral Rinses Targeting the Viral Lipid Envelope in SARS-CoV-2 Infection. Function (Oxf). 2020;1(1). [PubMed] [Google Scholar]

8. Meister TL, Bruggemann $\mathrm{Y}$, Todt D, Conzelmann C, Muller JA, Grob R, Munch J, Krawczyk A, Steinmann J, Steinmann J, Pfaender S, Steinmann E. Virucidal Efficacy of Different Oral Rinses Against Severe Acute Respiratory Syndrome Coronavirus 2. J Infect Dis. 2020 Sep;222(8):1289-92. [PubMed] [Google Scholar]

9. Vathanophas V, Pattamakajonpong $P$, Assanasen $P$, Suwanwech T. The effect of steam inhalation on nasal obstruction in patients with allergic rhinitis. Asian Pac J Allergy Immunol. 2019. [PubMed] [Google Scholar]

10. Sahin ONA, Gülen F. Approach to common cold in children. J Ped Res. 2015;2(1):1-6.

11. Szilagyi PG. Humidifiers and other symptomatic therapy for children with respiratory tract infections. Pediatr Infect Dis J. 1991;10(6):478-9. [PubMed]

12. Uy TMZ, Miranda MCB, Aro SJV, Uy MEV. Should steam inhalation be used in the treatment and prevention of COVID-19? Asia Pac Center Evid Based Healthcare. 2020;1:1-6. [Google Scholar]

13. Lowen AC, Mubareka S, Steel J, Palese P. Influenza virus transmission is dependent on relative humidity and temperature. PLoS Pathog. 2007;3(10):1470-6. [PubMed] [Google Scholar]

14. Chin AWH, Chu JTS, Perera MRA, Hui KPY, Yen HL, Chan MCW, Peiris M, Poon LLM. Stability of SARSCoV-2 in different environmental conditions. Med Rxiv. 2020;1:10. [Google Scholar]

15. Umoren R, Odey F, Meremikwu MM. Steam inhalation or humidified oxygen for acute bronchiolitis in children up to three years of age. Cochrane Database Syst Rev. 2011;(1):CD006435. [PubMed] [Google Scholar]

16. Gupta HV, Gupta VV, Kaur G, Baidwan AS, George PP, Shah JC, Shinde K, Malik R, Chitkara N, Bajaj KV. Effectiveness of $3 \%$ hypertonic saline nebulization in acute bronchiolitis among Indian children: A quasiexperimental study. Perspect Clin Res. 2016 AprJun;7(2):88-93. [PubMed] [Google Scholar]

17. Li Q, Guan X, Wu P, Wang X, Zhou L, Tong Y, Ren R, Leung KSM, Lau EHY, Wong JY, Xing X, Xiang N, Wu Y, Li C, Chen Q, Li D, Liu T, Zhao J, Liu M, Tu W, Chen C, Jin L, Yang R, Wang Q, Zhou S, Wang R, Liu H, Luo Y, Liu Y, Shao G, Li H, Tao Z, Yang Y, Deng Z, Liu B, Ma Z, Zhang Y, Shi G,
Lam TTY, Wu JT, Gao GF, Cowling BJ, Yang B, Leung GM, Feng Z. Early transmission dynamics in Wuhan, China, of Novel Coronavirus-infected pneumonia. N Engl J Med. 2020;382(13):1199-207. [PubMed] [Google Scholar]

18. He X, Lau EHY, Wu P, Deng J, Wang J, Hao X, Lau YC, Wong JY, Guan Y, Tan X, Mo X, Chen Y, Liao B, Chen W, Hu F, Zhang Q, Zhong M, Wu Y, Zhao L, Zhang F, Cowling BJ, Li F, Leung GM. Temporal dynamics in viral shedding and transmissibility of COVID-19. Nat Med. 2020;26(5):672-5. [PubMed] [Google Scholar]

19. Swain SK, Sahu A. Steam inhalation as an adjuvant treatment in Covid-19 positive health care professionals: Our Experiences at Tertiary Care Teaching Hospital. Int J Cur Res Rev. 2021;13(5). [Google Scholar] 